Epistēmēs Metron Logos, Issue 4

Epistēmēs Metron Logos Journal No 4 (2020)

DOI 10.12681/eml.24208

ISSN 2585-2973

\title{
Three new suggested guidelines for increased transparency regarding open access article processing charges (APCs)
}

\author{
Jaime A. Teixeira da Silva ${ }^{1}$
}

Abstract
The article processing charge (APC) lies at the heart of the gold open access (GOA)
business model. Small and larger society-based, as well as commercial publishers, rely -
to different extents - on the APC and the GOA model to thrive. There is wide debate
regarding what amount of APC is considered to be exploitative, and the issue of low APCs
is often erroneously associated with "predatory" OA publishing. Independent of this
debate, there is still, surprisingly, considerable opacity related to the APC used to cover
the cost of GOA. In a bid to increase transparency, a simple 3-point plan at increasing
academic and financial transparency of authors and journals/publishers regarding APCs is
proposed: 1) indicate which author paid the APC in multi-author papers; 2) indicate the
value of the APC paid; 3) provide online proof or certification of APC payment, including
the indication of any discounts or waivers.

Keywords: funding; opacity vs transparency; open access; open access mega-journal; Plan $\mathrm{S}$

\footnotetext{
${ }^{1}$ Independent researcher, P. O. Box 7, Miki-cho post office, Ikenobe 3011-2, Kagawa-ken, 761-0799, Japan jaimetex@yahoo.com
} 


\section{Epistēmēs Metron Logos, Issue 4}

Dear Epistemes Metron Logos Editors,

Open access (OA) lies at the heart of the current academic publishing platform, especially the issue of sustainability and who will foot the cost. Often subject to heated debate, the cost of paying for knowledge, via OA, is constantly at the fore of such discussions $^{2}$. On one extreme (fully scholarly objective) lies platinum OA, in which the publisher, institute or funder covers all costs associated with publication of intellect, and does not charge authors an article processing charge (APC). On the other extreme is subscription-based publishing that does not have publishing costs for authors, where copyright is usually transferred to the publishing entity, and where the option of converting an article to OA exists, at a cost, the APC, i.e., the gold open access (GOA) business model (Crawford, 2018; Morrison, 2018; Khoo, 2019; Asai, 2020). In between, one can find a whole range of academic and exploitative models, abuses of OA and of APCs, including "predatory" OA publishing and the black/pirate OA market (e.g., Sci-Hub) (Teixeira da Silva et al., 2019a) and the APC-metrics gaming model (Teixeira da Silva, 2017), a large, important and complex discussion that lies beyond the objectives and scope of this letter.

APCs also lie at the core of emerging OA publishing plans like Plan $\mathrm{S}^{3}$, mega publishing ventures such as OA mega-journals (Teixeira da Silva et al., 2019b), which can be profitable APC cash cows based on paper volume-APC ratios ${ }^{4}$, or new experimental publishing models such as Elsevier's OA mirror journals ${ }^{5}$, and given the gradually increasing value of the OA market ${ }^{6}$, and the constant debate regarding the sustainability of $\mathrm{OA}^{7}$, it makes sense to ensure that additional measures are in place to reduce, as much as possible, abuse, and to make the issue of APC accountability and transparency front and center of the OA debate. That said, not all academics are able to pay APCs, and it is not uncommon to find journals with APC waivers or discounts (Lawson, 2015).

One of the key tenants of fair, equitable and sustained academic publishing is the transparency of operations. Yet, for publicly or privately funded research published in

\footnotetext{
${ }^{2}$ https://poynder.blogspot.com/2020/02/plos-ceo-alison-mudditt-discusses-new.html (February 19, 2020; last accessed: June $30,2020)$.

${ }^{3}$ https://www.coalition-s.org/ (last accessed: June 30, 2020).

${ }_{4}$ https://scholarlykitchen.sspnet.org/2020/05/07/guest-post-the-megajournal-lifecycle/ (May 7, 2020; last accessed: June 30, 2020).

${ }^{5}$ https://www.elsevier.com/about/open-science/open-access/open-access-journals/mirror-journals (last accessed: June 30, 2020).

${ }^{6} \mathrm{https}$ ://deltathink.com/open-access-market-sizing-update-2019/ (November 17, 2019; last accessed: June 30, 2020).

7 https://sustainingknowledgecommons.org/2019/11/27/oa-apc-longitudinal-survey-2019/ (November 27, 2019; last accessed: June 30, 2020).
} 


\section{Epistēmēs Metron Logos, Issue 4}

OA journals or in subscription-based journals whose OA is covered by an APC, apart from an acknowledgement that indicates the funder or source of funding, it is rare or almost impossible to find the following details regarding the APC: 1) which author paid the APC in multi-author papers; 2) the value of the APC paid; 3) certification of APC payment, and/or an indication of any discounts or waivers. For example, one of the most widely accepted recommendations for publishing industry standards, by the $\mathrm{ICMJE}^{8}$, only provide a superficial guideline for journals that does not address these three aspects, and provide no guidance for authors. These gaps accentuate the weakness and porosity of such guidelines, reducing their effectiveness in serving as a tool of transparency for the publishing industry (Teixeira da Silva, 2020).

In order to address these gaps, three new guidelines are suggested, information that fits perfectly within an acknowledgement, and that would supplement journal requirements for APCs of submitting authors (e.g., Lubowitz et al., 2017):

1) When there are two or more authors in a manuscript, the author responsible for paying the APC should be clearly indicated. As a subset of this guideline, it should also be clearly indicated if the author, their institute, or a funder / funding agency covered the APC, or if there was shared responsibility.

2) The precise value of the APC that was paid, and the currency and date of receipt, should be indicated.

3) Any special agreements covered between the author, author's institute or funder and publisher to offer discounted APCs should be noted. Related to this, if the authors were offered a discount, the reason for the discount and the value of the discount should be clearly indicated.

The responsibility of the accuracy of these three aspects related to APCs should lie with the authors and with the editors. Apart from the issue of openness and transparency, especially in a publishing world clamoring for open science, these three simple guidelines would address the issues of fairness associated with the possibility of opaque backroom negotiations between authors and editors or publishers to lower APCs.

\section{Conflicts of interest}

The author declares no conflicts of interest of relevance to this topic.

\footnotetext{
${ }^{8}$ In section "F. Fees" (p. 11), the following is stated: "Journals should be transparent about their types of revenue streams. Any fees or charges that are required for manuscript processing and/or publishing materials in the journal shall be clearly stated in a place that is easy for potential authors to find prior to submitting their manuscripts for review or explained to authors before they begin preparing their manuscript for submission". http://www.icmje.org/icmje-recommendations.pdf (December, 2019; last accessed: June 30, 2020).
} 


\section{Epistēmēs Metron Logos, Issue 4}

\section{Author contributions}

The author contributed to all the intellectual discussion underlying this paper, literature exploration, writing, data collection and analysis and interpretation, reviews and editing, and accepts responsibility for the content of the paper.

\section{References}

Asai, S. (2020). Market power of publishers in setting article processing charges for open access journals. Scientometrics 123(2): 1037-1049. https://doi.org/10.1007/s11192-020-03402-y

Crawford. W. (2018). GOAJ3: Gold open access journals 2012-2017. 2018. https://walt.lishost.org/2018/05/goaj3-gold-open-access-journals-2012-2017/ (last accessed: June 30, 2020)

Khoo, S.T.-S. (2019). Article processing charge hyperinflation and price insensitivity: An open access sequel to the serials crisis. Liber Quarterly 29(1): 1-18. https://doi.org/10.18352/lq.10280

Lawson, S. (2015). Fee waivers for open access journals. Publications 3(3): 155-167. https://doi.org/10.3390/publications3030155

Lubowitz, J.H., Brand, J.C., Rossi, M.J., \& Provencher, M.T. (2017). "Open Access" requires clarification: medical journal publication models evolve. Arthroscopy 33(3): 497-499. https://doi.org/10.1016/j.arthro.2016.12.009

Morrison, H. (2018). Global OA APCs (APC) 2010-2017: Major trends. ELPUB 2018, 10.4000/proceedings.elpub.2018.16, Toronto, Canada. https://elpub.episciences.org/4604/pdf (last accessed: June 30, 2020).

Teixeira da Silva, J.A. (2017). The Journal Impact Factor (JIF): science publishing's miscalculating metric. Academic Questions 30(4): 433-441. http://doi.org/10.1007/s12129-017-9671-3

Teixeira da Silva, J.A. (2020). The ICMJE recommendations: challenges in fortifying publishing integrity. Irish Journal of Medical Science (in press) http://doi.org/10.1007/s11845-020-02227-1

Teixeira da Silva, J.A., Dobránszki, J., Tsigaris, P., Al-Khatib, A. (2019a) Predatory and exploitative behaviour in academic publishing: An assessment. The Journal of Academic Librarianship 102071. http://doi.org/10.1016/j.acalib.2019.102071

Teixeira da Silva, J.A., Tsigaris, P., Al-Khatib, A. (2019b). Open access megajournals: quality, economics and post-publication peer review infrastructure. Publishing Research Quarterly 35(3): 418-435. https://doi.org/10.1007/s12109-019$\underline{09654-8}$ 